\title{
The Impact of Market Orientation on Business Performance: Evidence from a Developing Country
}

\author{
SANY SANURI MOHD MOKHTAR \\ RUSHAMI ZIEN YUSOFF \\ College of Business \\ Universiti Utara Malaysia
}

\begin{abstract}
The main aim of this paper is to investigate the relationship between market orientation and business performance. Hypothesis concerning the relationship between market orientation and business performance were posited and tested. Data were collected using a mail questionnaire survey approach. This study employed a simple random sampling procedure in selecting the organisations for inclusion in the sample. A total of 158 Malaysian manufacturing organisations participated in this study. Factor analysis, Pearson correlation, and multiple regression methods of data analysis were utilised for hypotheses testing. The results revealed that market focus, market action, market planning, market feedback, and market coordination jointly explained $32.6 \%$ of the variance of business performance. Market focus and market coordination were found to have statistically significant association with business performance. The outcome of this study provides vital information from a developing country perspective on the impact of market orientation practices on manufacturing organisations' performance.
\end{abstract}

\begin{abstract}
ABSTRAK
Kajian ini dijalankan untuk membuat pengamatan ke atas hubungan di antara orientasi pasaran dengan prestasi perniagaan organisasi. Hipotesis berkaitan hubungan di antara orientasi pasaran dan prestasi perniagaan organisasi dikemukakan untuk diuji. Data telah dikumpulkan melalui kaedah tinjauan mel dengan bantuan soal selidik. Pemilihan organisasi sebagai sampel untuk kajian ini menggunakan prosedur rawak mudah. Seratus lima puluh lapan organisasi pembuatan di Malaysia terlibat dalam kajian ini. Kaedah analisis faktor, korelasi Pearson dan regresi berganda telah digunakan untuk menguji hipotesis. Keputusan menunjukkan fokus pasaran, tindakan pasaran, perancangan pasaran, maklum balas pasaran dan koordinasi pasaran secara kolektifnya menerangkan $32.6 \%$ varians dalam prestasi pelanggan. Fokus pelanggan dan koordinasi pasaran didapati mempunyai hubungan statistik yang signifikan dengan prestasi pelanggan. Hasil kajian ini telah memberikan maklumat yang penting dari perspektif negara membangun terhadap impak amalan orientasi pasaran kepada prestasi organisasi pembuatan di Malaysia.
\end{abstract}

\section{INTRODUCTION}

Recent years of the globalisation process have witnessed a renewed importance on delivering superior quality products that meet customer needs. As the impact of globalisation, the World Trade Organisation and free trade agreements led to the opening up of the local market, Malaysian organisations need to adapt to the changes that take place in the market. Tan Sri Azman Hashim, 
the Malaysian Industry Excellence Award council chairman, identified that the key to succeed in the market place is innovation, branding, and marketing since the marketplace is international and organisations need to compete with the best in the world (Chong, 2007). This is especially so in the case of a small economy like Malaysia where a relatively small market exists domestically. As noted by the Malaysian government, Malaysia has to face greater challenges in this current period of increasing competition and volatile global environment (Economic Planning Unit, 2005). The current situation requires the Malaysian organisations to continuously redefine and re-establish the factors that will allow them to maintain their competitive edge and survival in this new economy environment (Agus, 2004). Thus, the mid-term review report of the Eighth Malaysia Plan urged organisations to improve their competitiveness by specifying them to take initiatives in increasing productivity to reduce cost of production, increase the quality of product or services, and raise organisational marketing capability, especially to exports market (Economic Planning Unit, 2005).

Although the service sector is growing in importance, the manufacturing sector still plays a significant role in the Malaysian economy by contributing an average of $30 \%$ to the overall Gross Domestic Product (GDP), 80\% of the total export, and $30 \%$ of the total employment in the past years (Economic Planning Unit, 2005). In the year 2005, the manufacturing sector contributed $31.5 \%$ of GDP, $81.6 \%$ of total export, and $28.3 \%$ of total employment (MoF, 2006). These figures indicated the importance of manufacturing organisations to become a market-oriented firm or practise market orientation in ensuring survival, maintaining and improving business performance.

This study helps to enhance the knowledge of market orientation by investigating the impact of market orientation on business performance by providing empirical evidence in the context of a developing country perspective. Therefore, one of the aims of this study was to fill in this gap by looking at the impact of market orientation on business performance of manufacturing organisations in Malaysia. The selection of this country is appropriate since it is a developing country whose vision is to be a developed nation by 2020 . It was assumed that the organisational culture of this country is unique to the country specific factors, such as the people and the business environment it operates in.

\section{Market Orientation Development}

It has been generally agreed that marketing concept is the foundation theory of market orientation (Kohli \& Jaworski, 1990; McCarthy \& Perreault, 1993; Narver \& Slater, 1990; Trustrum, 1989).

Generally, from the definitions of marketing concept provided by the literature, the three common basic elements of marketing concept includes customer orientation, integration and coordination, and profit orientation (Barksdale \& Darden, 1971; Felton, 1959; McNamara, 1972; Webster, 1988).

Customer orientation constitutes identifying customer needs and satisfying them in meeting the organisational goals (Barksdale \& Darden, 1971; Felton, 1959; Kotler \& Levy, 1969; McNamara, 1972). This element of marketing concept was first discussed by Peter Drucker in 1950s, who argued that marketing was a general management responsibility. He also suggested that there was only one definition of marketing concept, which is to create customers and then satisfy the customer (Webster, 1988) .

There is only one valid definition
of business purpose: to create and
satisfy customer. It is the customer
who determines what the business
is. Because it is its purpose to
create a customer, any business
enterprise has two-and only these
two - basic functions: marketing
and innovation...Actually marketing
is so basic that is not just enough
to have strong sales force and to
entrust marketing to it. Marketing
is not only broader than selling; it
is not a specialised activity at all.
It is the whole business seen from
the point of view of its final result,


that is, from the customer's point of view (p.31).

He elaborated further that marketing should be seen as a whole business that takes into account the customer's point of view. Some literature agreed that there is a need for integration and coordination among all the departments in meeting and satisfying customers (Felton, 1959; Munsinger, 1964). For instance, Felton (1959) stressed that all the board of directors and senior management should develop a proper marketing state of mind, and integration and coordination in the organisation for meeting corporate objectives. The company-wide focus on external customers should not be the sole responsibility of marketing department but every function needs to play an active role in meeting and satisfying consumer needs. As specified by Kotler (1972), "the marketing concept is a customer orientation backed by integration marketing aimed at generating customer satisfaction as the key to satisfying organisational goals". Hooley, Lynch, and Shepherd (1990) also suggested that for an organisation to improve their business performance, marketing should be viewed as a guiding philosophy for the entire organisation, rather than as another department function.

From the argument above, it is apparent that the objective of business is to create a satisfied customer. The whole organisation should involved in working towards meeting the customers' needs and does not only depends on the marketing alone. However, some studies go even further to include profit orientation as part of the marketing concept (Barksdale \& Darden, 1971; Kotler, 2003). For instance, Barksdale and Darden (1971) noted that there are two fundamental notions of the marketing concept: "First, the consumer is recognised as the focal point or pivot for all business activity. Second, profit-rather than sales volume is specified as the criterion for evaluating marketing activities". The emphasis of the definition here is on the recognition of customer as the centre point of operation and profit as the standard for measuring marketing activities.

Based on the argument above, it is commonly agreed that customer orientation, coordination between departments, and profit orientation are the basic elements of the marketing concept. However, the emphasis on this philosophy is still vague and theoretical in nature without any suggestion on how to implement the concept. The marketing concept noted the importance of customer orientation and satisfaction, integration and coordination, and profit orientation, but it did not suggest how the organisation can successfully embrace or implement the concept. Thus, market orientation was conceptualised and the term market orientation has been used to mean the implementation of marketing concept (Kohli \& Jaworski, 1990; McCarthy \& Perreault, 1993). In other words, market orientation is the degree to which marketing concept has been adopted by an organisation (McCarthy \& Perreault, 1993; Parasuraman, 1981; Trustrum, 1989). It was also argued that the adoption of marketing concept should not be specific to one department, but all departments adopt and work as a total system rather than working separately (McCarthy \& Perreault, 1993).

Recent development of marketing literature suggested that there are few main publications that have conceptualised and revitalised market orientation. The most popular and highly cited in market orientation literature are by Kohli and Jaworski (1990) and Narver and Slater (1990). These authors have put in a new perspective of marketing concept, which was regarded as a business philosophy by operationalising the marketing concept. The operationalisation is reflected in the activities and behaviours of an organisation, rather than just a business philosophy as marketing concept was known (Diamantopoulos \& Hart, 1993; Kohli \& Jaworski, 1990).

Kohli and Jaworski (1990) defined market orientation as "the organisation wide generation of market intelligence pertaining to current and future customer needs, dissemination of the intelligence across departments, and organisation wide responsiveness to it".

Three main activities underlying this definition are generation of market intelligence, dissemination of intelligence, and responsiveness to market intelligence. These activities represent 
customer orientation and coordination elements of the marketing concept. As specified by Kohli and Jaworski (1990), "the meaning of the market orientation construct that surfaced in the field is essentially a more precise and operational view of the first two pillars of the marketing concept - customer focus and coordination". According to them intelligence generation should not be seen as a narrow concept, whereby an organisation obtains the information on customer needs. However, the generation of intelligence should include obtaining information from other exogenous factors outside the organisation system, such as government regulation, technology, competitors, and environmental forces. In other words, the focus of obtaining information is the market that involves end users, distributors, and other external forces that affect customer needs and preferences. In addition the information obtained is not limited to the current needs, but also future needs of the customer, since it is important for an organisation to develop a new product offering.

Narver and Slater viewed market orientation as an organisational culture that forces a business to achieve sustainable competitive advantage by creating superior value for customers (Narver \& Slater, 1990). Thus, market orientation has been defined by them "as the organisation culture that most effectively and efficiently creates the necessary behaviours for the creation of superior value for buyers and, thus, continuous superior performance for the business" (Narver \& Slater, 1990). Three behavioural components, customer orientation, competitor orientation and interfunctional coordination, represent the operationalisation of marketing concept as they involve activities in the organisation to create superior value for the customer.

Although definitions of market orientation provided by Kohli and Jaworski (1990) and Narver and Slater (1990) had featured in most market orientation studies, the definition of market orientation has been further developed. Many scholars had come out with new definitions that extend the definition of Kohli and Jaworski (1990) and Narver and Slater (1990) with the purpose of improving it and offering new alternatives based on their studies.

\section{Market Orientation and Business Performance}

Market orientation has been linked to business performance since it provides firms with sustainable competitive advantage (Narver \& Slater, 1990) and capabilities (Day, 1994) that set the organisation ahead of competitors. Sustainable competitive advantage can be attained by creating the necessary behaviours to deliver superior value to customers (Narver \& Slater, 1990). On the other hand, capabilities can be attained through acquiring the necessary skills, which ensure coordination of functional activities that direct the organisation to anticipate and respond to changing market requirements to achieve superior performance (Day, 1994). Thus, a market oriented organisation performs better in the market since the activities involved are directed towards identifying and responding to customer needs and satisfying customers (Jaworski \& Kohli, 1993). Further argument also noted that market oriented organisational culture is a strong source of competitive advantage (Pelham \& Wilson, 1996, Pelham, 1997).

One of the first empirical studies that tested the link between market orientation and business performance was by Narver and Slater (1990). They developed a measure of market orientation and tested its effect on business profitability using a sample of 140 business units, consisting of commodity products businesses and noncommodity businesses. The study found out that market orientation and business performance was significantly related to the profitability of the business. Profitability was measured using managers' assessment on return on assets (ROA) in relation to competitors over the past year. In another study, the effect of market orientation on employee and business performance was also investigated and the results found a positive support for both variables, but no relationship was found in the study between market orientation and market share (Jaworski \& Kohli, 1993).

Since then, there have been many studies (Pelham, 1997; Pulendran, Speed, \& Widing, 2000; Ruekert, 1992) that have linked market orientation and business performance. Most of the studies (Pelham \& Wilson, 1996; Pitt, Caruana, \& 
Berthon, 1996; Pulendran et al., 2000) had found a positive association between market orientation and performance. However, there are a few cases that had found no linked or weak association on these relationships. For example, Greenly (1995) identified that market orientation was not significantly related to performance. Besides, a weak association was also found between market orientation and performance (Diamantopoulos \& Hart, 1993).

A review of the literature found that early studies (Diamantopoulos \& Hart, 1993; Pitt et al., 1996; Ruekert, 1992) between market orientation and performance have been conducted in the United States of America (USA) and United Kingdom (UK). Later on, there have been many studies that examined the relationship between market orientation and performance in different national contexts (Appiah-Adu, 1998; Bhuian, 1997; Pulendran et al., 2000; Soehadi, Hart, \&
Tagg, 2001). Pitt, et al. (1996) in their study of market orientation and business performance in the UK and Malta suggested that the effect on performance of both countries were similar. Research in Hong Kong and mainland China also suggested that market orientation has a significant and positive impact on the performance of firms (Sin \& Tse, 2000). Although most of the studies supported the association between market orientation and performance, some studies showed opposite associations in these relationships. For instance, market orientation was found not significantly related to new product performance and business performance in Holland (Langerak, Hultink, \& Robben, 2004). Study in Ghana (Appiah-Adu, 1998) and Saudi Arabia (Bhuian, 1997) also indicated that market orientation was not related to performance. Table 1 below provide a summary of selected studies on the market orientation and performance relationship.

Table 1

Summary of Selected Studies on Market Orientation and Performance

\begin{tabular}{|c|c|c|c|c|c|c|}
\hline Studies & $\begin{array}{l}\text { Industry } \\
\text { (Sample Size) }\end{array}$ & Country & $\begin{array}{l}\text { Analytical } \\
\text { Approach }\end{array}$ & $\begin{array}{l}\text { Market Orientation } \\
\text { Scale }\end{array}$ & $\begin{array}{l}\text { Performance } \\
\text { Measure }\end{array}$ & $\begin{array}{l}\text { Summary of Key } \\
\text { Findings }\end{array}$ \\
\hline $\begin{array}{l}\text { Appiah-Adu \& } \\
\text { Ranchhod (1998) }\end{array}$ & $\begin{array}{l}\text { Biotechnology } \\
\text { Industry } \\
(62)\end{array}$ & UK & Regression & $\begin{array}{l}\text { Adapted Narver \& } \\
\text { Slater (1990) }\end{array}$ & $\begin{array}{ll}\text { - } & \text { New Product } \\
\text { success } \\
\text { - } & \text { Market share } \\
\text { growth } \\
\text { - } \text { Profit Margin } \\
\text { - } \text { Overall } \\
\text { Performance }\end{array}$ & $\begin{array}{l}\text { Market orientation } \\
\text { is significantly } \\
\text { related to market } \\
\text { share growth, profit } \\
\text { margins and overall } \\
\text { performance but not } \\
\text { significantly related } \\
\text { to new product } \\
\text { success. }\end{array}$ \\
\hline $\begin{array}{l}\text { Appiah-Adu } \\
\text { (1998) }\end{array}$ & $\begin{array}{l}\text { Manufacturing } \\
\text { \& Services } \\
\text { (74) }\end{array}$ & Ghana & $\begin{array}{l}\text { Regression } \\
\text { Analysis }\end{array}$ & 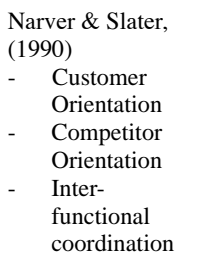 & $\begin{array}{l}\text { - Sales growth } \\
\text { - Return on } \\
\text { investment } \\
\text { (ROI) }\end{array}$ & $\begin{array}{l}\text { Market orientation } \\
\text { was not significantly } \\
\text { related to sales } \\
\text { growth and ROI } \\
\text { performance. }\end{array}$ \\
\hline $\begin{array}{l}\text { Baker \& Sinkula } \\
\text { (1999) }\end{array}$ & $\begin{array}{l}\text { Large multi- } \\
\text { industry } \\
(411)\end{array}$ & USA & Regression & $\begin{array}{l}\text { Kohli et al. (1993) } \\
\text { MARKOR }\end{array}$ & $\begin{array}{ll}\text { - } & \text { New product } \\
\text { success } \\
\text { - } & \text { overall } \\
\text { performance } \\
\text { - } \quad \text { change in } \\
\text { market share } \\
\text { relative to the } \\
\text { firms largest } \\
\text { competitors }\end{array}$ & $\begin{array}{l}\text { Market orientation } \\
\text { was significantly } \\
\text { related to new } \\
\text { product success, } \\
\text { overall performance } \\
\text { and change in } \\
\text { market share. }\end{array}$ \\
\hline
\end{tabular}


(continued)

\begin{tabular}{|c|c|c|c|c|c|c|}
\hline Bhuian (1997) & $\begin{array}{l}\text { Services } \\
(92)\end{array}$ & $\begin{array}{l}\text { Saudi } \\
\text { Arabia }\end{array}$ & Regression & $\begin{array}{l}\text { Jaworski \& Kohli } \\
\begin{array}{ll}\text { (1993) } \\
-\quad \text { Market } \\
\text { Intelligence } \\
\text { generation } \\
\text { - } \quad \text { Market } \\
\quad \text { Intelligence } \\
\quad \text { Dissemination } \\
\text { - } \quad \text { Responsiveness }\end{array}\end{array}$ & $\begin{array}{ll}\text { - } & \text { Return on } \\
& \text { Asset } \\
\text { - } & \text { Return on } \\
& \text { equity } \\
\text { - } & \text { Sales per } \\
& \text { employee }\end{array}$ & $\begin{array}{l}\text { Market orientation } \\
\text { was not significantly } \\
\text { related to banks } \\
\text { ROA, ROE, and } \\
\text { sales per employee. }\end{array}$ \\
\hline $\begin{array}{l}\text { Cadogan, } \\
\text { Diamantopoulous } \\
\text { \& Siguaw (2002) }\end{array}$ & $\begin{array}{l}\text { Mix firms } \\
(206)\end{array}$ & USA & $\begin{array}{l}\text { Structural } \\
\text { equation } \\
\text { modelling }\end{array}$ & $\begin{array}{l}\text { Cadogan, } \\
\text { Diamantopoulous, } \\
\text { \& de Mortanges' } \\
\text { (1999) }\end{array}$ & $\begin{array}{ll}\text { - } & \text { Export sales } \\
& \text { growth } \\
- & \text { Satisfaction } \\
- & \text { Overall } \\
& \text { performance }\end{array}$ & $\begin{array}{l}\text { Export market } \\
\text { orientation was } \\
\text { significantly related } \\
\text { to satisfaction and } \\
\text { overall performance. }\end{array}$ \\
\hline $\begin{array}{l}\text { Caruana, Pitt, \& } \\
\text { Berthon (1999) }\end{array}$ & $\begin{array}{l}\text { Large Service } \\
\text { firms } \\
(131)\end{array}$ & UK & Path analysis & $\begin{array}{l}\text { Jaworski \& Kohli } \\
\text { (1993) }\end{array}$ & $\begin{array}{ll}\text { - } & \text { Overall } \\
\text { performance }\end{array}$ & $\begin{array}{l}\text { Market orientation } \\
\text { was not significantly } \\
\text { related to business } \\
\text { performance. }\end{array}$ \\
\hline Dawes (2000) & $\begin{array}{l}\text { Multi-firms } \\
\text { (93) }\end{array}$ & $\begin{array}{l}\text { South } \\
\text { Australia }\end{array}$ & $\begin{array}{l}\text { Multiple } \\
\text { regression }\end{array}$ & $\begin{array}{l}\text { New \& existing } \\
\text { scales adapted } \\
\text { from Kohli } \\
\text { et al. }(1993) ; \\
\text { Narver \& } \\
\text { Slater (1990); } \\
\text { Deshpande } \\
\text { et al. }(1993) ; \\
\text { Deng \& } \\
\text { Dart (1994); } \\
\text { Faulkner } \\
\text { (1998); Pelham } \\
\text { \& Wilson } \\
\text { (1996) }\end{array}$ & Profitability & $\begin{array}{l}\text { Competitor } \\
\text { orientation is } \\
\text { significantly } \\
\text { related to company } \\
\text { profitability but } \\
\text { customer analysis } \\
\text { and responsiveness } \\
\text { are not significant. }\end{array}$ \\
\hline $\begin{array}{l}\text { Deshpande, Farley, } \\
\& \text { Webster (1993) }\end{array}$ & $\begin{array}{l}\text { Mix Firms } \\
\text { (50 } \\
\text { - Quadrads) } \\
\text { - Large Public } \\
\text { firms }\end{array}$ & Japan & $\begin{array}{l}\text { Discriminant } \\
\text { function }\end{array}$ & $\begin{array}{ll}\text { - } & \begin{array}{l}\text { Customer } \\
\text { orientation } \\
\text { (personal }\end{array} \\
\text { interview } \\
\text { \& literature } \\
\text { review) } \\
\text { customer } \\
\text { orientation }\end{array}$ & $\begin{array}{ll}\text { - } & \text { Profitability } \\
\text { - } & \text { Size } \\
\text { - } & \text { Market share } \\
\text { - } & \text { Growth rate }\end{array}$ & $\begin{array}{l}\text { Customer } \\
\text { orientation based on } \\
\text { customer assessment } \\
\text { is related positively } \\
\text { to performance, } \\
\text { however, manager } \\
\text { assessment is not } \\
\text { related to business } \\
\text { performance }\end{array}$ \\
\hline $\begin{array}{l}\text { Diamantopoulos } \\
\& \text { Hart (1993) }\end{array}$ & $\begin{array}{l}\text { Manufacturing } \\
\text { firms } \\
\text { (87) }\end{array}$ & UK & T-test & $\begin{array}{l}\text { Jaworski \& Kohli } \\
\begin{array}{cl}\text { (1993) } \\
\text { - } & \text { Market } \\
& \text { Intelligence } \\
& \text { generation } \\
- & \text { Market } \\
& \text { Intelligence } \\
& \text { Dissemination } \\
-\quad & \text { Responsiveness }\end{array}\end{array}$ & $\begin{array}{ll}- & \text { Sales growth } \\
\text { - } & \text { Profit }\end{array}$ & $\begin{array}{l}\text { Weak association } \\
\text { between market } \\
\text { orientation and } \\
\text { performance (sales } \\
\text { growth and profit). }\end{array}$ \\
\hline Ellis (2005) & $\begin{array}{l}\text { Exporter } \\
\text { manufacturer } \\
(57)\end{array}$ & China & $\begin{array}{l}\text { Multiple } \\
\text { Regression }\end{array}$ & $\begin{array}{ll}\text { Narver \& Slater, } \\
\begin{array}{ll}(1990) \\
- & \text { Customer } \\
& \text { Orientation } \\
- & \text { Competitor } \\
& \text { Orientation } \\
- & \text { Inter-functional }\end{array}\end{array}$ & $\begin{array}{ll}\text { - } & \text { Satisfaction } \\
\text { with } \\
\text { performance } \\
\text { - } & \text { Performance } \\
\text { in comparison } \\
\text { with major } \\
\text { competitors } \\
\text { - Overall } \\
\text { performance } \\
\text { based } \\
\text { on sales } \\
\text { growth and } \\
\text { profitability }\end{array}$ & $\begin{array}{l}\text { Market orientation } \\
\text { was significantly } \\
\text { related to } \\
\text { competitive } \\
\text { performance but } \\
\text { not satisfaction } \\
\text { performance and } \\
\text { overall performance. } \\
\text { Marketing practice } \\
\text { was significantly } \\
\text { related to } \\
\text { satisfaction and } \\
\text { overall performance. }\end{array}$ \\
\hline
\end{tabular}


(continued)

\begin{tabular}{|c|c|c|c|c|c|c|}
\hline Farell (2000) & $\begin{array}{l}\text { Manufacturing } \\
\text { \& services } \\
\text {-large } \\
\text { organisations } \\
(268)\end{array}$ & Australia & $\begin{array}{l}\text { Two-stage } \\
\text { least square } \\
\text { multiple } \\
\text { regression }\end{array}$ & $\begin{array}{l}\text { Narver \& Slater } \\
\begin{array}{ll}(1990) \\
-\quad & \text { Customer } \\
& \text { Orientation } \\
-\quad & \text { Competitor } \\
& \text { Orientation } \\
-\quad & \text { Inter-functional } \\
& \text { coordination }\end{array}\end{array}$ & $\begin{array}{ll}\text { - } & \text { Customer } \\
& \text { retention } \\
- & \text { New product } \\
& \text { success } \\
- & \text { Sales growth } \\
- & \text { Return on } \\
& \text { investment } \\
- & \text { Overall } \\
& \text { performance }\end{array}$ & $\begin{array}{l}\text { Both market } \\
\text { orientation and } \\
\text { learning organisation } \\
\text { were significantly } \\
\text { and positively } \\
\text { related to business } \\
\text { performance. }\end{array}$ \\
\hline $\begin{array}{l}\text { Gray, Matear, } \\
\text { Boshoff, \& } \\
\text { Matheson (1998) }\end{array}$ & $\begin{array}{l}\text { Mix } \\
\text { companies } \\
(490)\end{array}$ & $\begin{array}{l}\text { New } \\
\text { Zealand }\end{array}$ & Correlation & $\begin{array}{l}\text { Deng \& Dart } \\
\text { (1994); Jaworski \& } \\
\text { Kohli (1993); Nar- } \\
\text { ver \& Slater(1990) }\end{array}$ & $\begin{array}{ll}\text { - } & \text { Return on } \\
\text { Investment } \\
\text { - } & \text { Brand } \\
& \text { awareness, } \\
\text { - } & \text { - Customer } \\
\text { satisfaction } \\
\text { and loyalty }\end{array}$ & $\begin{array}{l}\text { Overall market } \\
\text { orientation was } \\
\text { significantly } \\
\text { related to return on } \\
\text { investment, brand } \\
\text { awareness, customer } \\
\text { satisfaction, and } \\
\text { customer loyalty. }\end{array}$ \\
\hline
\end{tabular}

There has not been much effort for studies to be conducted in the developing nations, although these countries are moving toward a free market-orientation from centralised economies (Appiah-Adu, 1998). It was assumed that a successful market orientation on organisations based in western cultures will apply to any culture. However, it was suggested that countryspecific factors may affect the market-oriented culture (Yoon \& Lee, 2005). Only in recent studies, empirical market orientation studies had been conducted in a transition and developing economies such as Ghana (Appiah-Adu, 1998), Saudi Arabia (Bhuian, 1997), China (Ellis, 2005), Hong Kong (Sin, Tse, Yau, Lee, \& Chow, 2004), Korea (Yoon \& Lee, 2005), and Taiwan (Lee $\&$ Tsai, 2005). However, there has been mixed results on the findings. Some studies (Horng \& Cheng-Hsui Chen, 1998; Lee \& Tsai, 2005; Loubser, 2000; Sin et al., 2004; Soehadi et al., 2001) indicated a positive association between market orientation and performance, while some studies showed no association between market orientation and performance (Appiah-Adu, 1998; Bhuian, 1997).

There are two reasons for the difference between studies in developed and developing countries. One of the differences is the behaviour of the consumer, whereby consumers in developed countries are sophisticated and conscious of their rights; hence, in order to be competitive, firms need to pay attention to consumer needs (Kuada \& Buatsi, 2005). Another reason is the high intensity of competition among firms in these developed countries leading firms to strive for higher performance in order to survive (Kuada \& Buatsi, 2005). This notion indicated that market orientation was perceived as more important in developed countries compared to developing countries. For instance, a study found that foreign companies and managers which are based in the developed nations operating in developing countries tend to perform more marketing activities than the domestic companies (AppiahAdu, 1998).

Thus, based on the past findings, there has been a call for more research to focus on developing nations (Appiah-Adu, 1998; Ellis, 2005; Kuada \& Buatsi, 2005) and other countries besides USA in which the business environment differs (Sin et al., 2004). This will ensure that market orientation is not a concept unique to US companies (Ellis, 2005). A recent study has also supported that the relationship between market orientation and performance were different between the USA and other nations (Shoham \& Rose, 2001).

The business performance measures employed in previous study can be categorised into two main groups: (a) financial performance and (b) 
non-financial performance measures. Examples on some of the financial performance indicators employed in previous study are profitability, return on investment, sales growth, and return on asset. Examples of non-financial performance indicators include, customer satisfaction, new product success, customer retention, organisational commitment, product quality, and productivity (Kaplan \& Norton, 1992, 1993, 1996a, 1996b, 2001; Pitt et al., 1996; Singh, 2004; Slater \& Narver, 1994; Vorhies \& Harker, 2000).

According to Sinclair and Zairi (1995), the use of particular measures needs to be linked with the interest of the stakeholders. However, there had been many criticisms on previous performance measures that focus on management control systems and financial indicators, such as cost accounting and profitability (Chakravarthy, 1986; Gomes, Yasin, \& Lisboa, 2004; Sinclair \& Zairi, 1995; Venkatraman \& Ramanujam, 1986). This concept of business performance was criticised because of its narrowed perspectives, since it focuses only on fulfilling the economic goals of the organisation (Venkatraman, \& Ramanujam, 1986) that excludes the transformation processes within the firm (Chakravarthy, 1986). Moreover, this traditional accounting/financial measurement system encourages short-term thinking (Gomes et al., 2004; Kaplan, 1983), ignore customers and their needs (Gomes et al., 2004), and does not guarantee excellence (Chakravarthy, 1986).

Thus, a broader conceptualisation of business performance that focuses on nonfinancial indicators or operational performance such as market-share, new product introduction, and technological efficiency, need to be taken into account in developing performance measures (Sinclair \& Zairi, 1995; Venkatraman \& Ramanujam, 1986). Moreover, the highly competitive business environment and the need to link the organisational strategy with performance have led many organisations adopting multiple dimensions of business performance that include both financial and non-financial performance indicators. Multiple dimensions of performance offer a more comprehensive operationalisation of business performance (Venkatraman \& Ramanujam, 1986).
In view of the above arguments, it was noted that most of the studies on market orientation have been limited to a few countries particularly, USA and UK. Thus, generalisation of the study could not be made to other countries since the business culture, and environment and regulations are different from one country to another.

Based on the previous argument of literature, we hypothesised the following hypothesis:

H1. Market orientation is positively associated with business performance

\section{METHODS}

The population of this study comprises all the manufacturing organisations in Malaysia that includes West and East Malaysia. The study used the whole organisation or strategic business unit of an organisation as the unit of analysis. Sampling frame for the study was taken from the Federation of Malaysian Manufacturers (FMM) directory in 2005. There are about 2000 manufacturing and industrial service organisations registered with FMM. Given the amount of this population size, the sample size that was taken into consideration in this study is 322 to warrant a good decision model (Krejcie \& Morgan, 1970). However, the questionnaire was distributed randomly to 500 manufacturing organisations. Of the 500 questionnaires posted, 158 complete questionnaires were returned representing a $31.6 \%$ response rate.

A key informant technique was employed in this study, since it is widely used in the marketing literature (Appiah-Adu, 1998; Diamantopoulos \& Hart, 1993; Greenley, 1995). This technique is suitable in the study for the reason that the content of the questionnaire requires complete or in-depth information, which cannot be expected from general respondents (Kumar, Stern, \& Anderson, 1993). The individuals selected to answer the questionnaire in this study are assumed to have specific knowledge in market orientation practices in the organization. Therefore, for this study it was identified that marketing managers had the specific knowledge of marketing in their respective organisation. The survey method strategy was 
employed to collect the data with regard to market orientation practices and managers' perception of the organisations' performance. The method of data collection for this study was carried out using a mail questionnaire survey approach.

\section{MEASURES}

Market orientation construct measures the extent of market orientation practices in the organisation. The construct consists of four main dimensions and measured by 26 items instrument adapted from past study measures by Gray et al. (1998), Kohli and Jaworski (1993), and Narver and Slater (1990) using a six-point item scale. The four dimensions derived from the conceptualisation of market orientation are: (1) customer focus, (2) market intelligence generation, (3) market dissemination, and (4) responsiveness. Examples of items that measure these dimensions are:

- "Our strategy for competitive advantage is based on our understanding of customer's needs" (customer focus)

- "Our organisation meets customers at least once a year to find out what product they will need in the future" (market intelligence generation)

- "Our organisation disseminates data on customer satisfaction at all levels in the organisation on a regular basis" (market dissemination)

- "Several departments get togetherperiodically to plan a response to changes taking place in our business environment" (responsiveness)

Factor analysis was carried out on these items. The result of factor analysis for market orientation showed that five factors had emerged, with factor loadings ranging from 0.664 to 0.846 , with six items eliminated. The measure of sampling adequacy (MSA) was 0.830 , which was higher than the recommended value of 0.60 and the Bartlett's Test of Sphericity was significant. The percentage of total variance explained by the five factors was $66.74 \%$. The first factor was defined by seven items and reflected the organisational action in detecting and taking action toward market changes in the business environment. Thus, this factor was named "Market Action". The second factor was dominated by items relating to customer focus, which are oriented toward creating customer value. Therefore, this factor was named "Market Focus". The third factor consisted of items pertaining to meeting and planning in responding toward market trend and development, thus this factor was named "Market Planning". The fourth factor consisted of items related to customer data collection on customer needs and satisfaction; hence this factor was named "Market Feedback". The fifth factor was dominated by items relating to sharing of information and working together between departments, especially on the data collected from the market, thus this factor was named "Market Coordination".

The results of the factor analysis lend support to convergent validity as each item in the same factor was highly correlated. The factors were also distinct from one another, grouped into five separate factors, hence lending support for discriminant validity. Table 2 below provides a summary of factor and reliability analysis of market orientation variables.

The dependent variable, business performance construct measures the degree of perceived performance of the organisation over the last three years. It was measured with four items adapted from past studies measurement (Kaplan \& Norton, 1992; Narver \& Slater, 1990; Singh, 2004; Vorhies \& Harker, 2000) using a six-point item scale.

Due to the creation of new variables as a result of factor analyses, new hypotheses were introduced and referred to throughout the findings of the study.

H1(a): Market action is positively associated with business performance

H1(b): Market focus is positively associated with business performance

H1(c): Market planning is positively associated with business performance

H1(d): Market feedback is positively associated with business performance

H1(e): Market coordination is positively associated with business performance 
Table 2

Factor \& Reliability Analysis of Market Orientation Variables

\begin{tabular}{lllllll}
\hline \multirow{2}{*}{ Items } & Factors & Mean & SD & $\begin{array}{c}\text { Percentage of } \\
\text { Variance }\end{array}$ & Loading & $\begin{array}{c}\alpha \\
\text { value }\end{array}$ \\
\hline
\end{tabular}

Detect changes on customers

product preferences

Detect fundamental shifts in the

industry

Alert other departments about the

$692 \quad 0.85$

Competitors price changes

response

30.281

needs

Resolution on customer complaints

Implementation of marketing plan

Business objectives driven by

customer satisfaction

Competitive advantage based on understanding of customer needs

Encourage customer comments and complaints

Market Focus

$\begin{array}{lll}5.194 \quad 680 & .68\end{array}$

0.88

Strong customer commitments

Creating customer value in the products

Interdepartmental meetings to discuss market trends and developments

Conduct market research (Market needs analysis)

Several departments meet periodically to plan changes taking place in business environment

Organisation response

immediately toward competitor

intensive campaign

Meet customer at least once a year to find out future product need

Polls customer at least once a year to assess product quality

Market

Feedback

The whole organisation knows within a short period if something happens to major customer

Market

Disseminate data on customer satisfaction at all levels in the organisation on a regular basis

$4.636 \quad 1.172$

6.871

$4.443 \quad .918 \quad 8.957$

0.75 


\section{RESULTS}

Multiple regression analysis was conducted to determine the relationship between market orientation variables with business performance. Simultaneously, regression analysis identifies the most contributory explanatory variables among the set of market orientation variables that best predict business performance.

Table 3 and 4 demonstrate the results of multiple regression analysis between market orientation and business performance.

Table 3

Multiple Regression Result between Market Orientation and Performance

\begin{tabular}{cccccc}
\hline $\mathrm{R}$ & R Square & $\begin{array}{c}\text { Adjusted R } \\
\text { Square }\end{array}$ & $\begin{array}{c}\text { Std. Error of the } \\
\text { Estimate }\end{array}$ & F & Sig. F \\
\hline .571 & .326 & .303 & .57710 & 14.203 & .000 \\
\hline
\end{tabular}

Table 4

Multiple Regression Result between Market Orientation Dimensions and Performance

\begin{tabular}{lccccc}
\hline \multicolumn{1}{c}{ Variables } & \multicolumn{2}{c}{ Unstandardised Coefficients } & $\begin{array}{c}\text { Standardised } \\
\text { Coefficients }\end{array}$ & $\mathrm{t}$ & Sig. \\
& $\mathrm{B}$ & Std. Error & Beta & & \\
\hline (Constant) & 1.372 & .394 & & 3.479 & .001 \\
Market Focus & .285 & .082 & .281 & 3.465 & $.001^{* *}$ \\
Market Action & .099 & .051 & .141 & 1.965 & .051 \\
Market Planning & .073 & .065 & .097 & 1.134 & .258 \\
Market Coordination & .118 & .053 & .180 & 2.224 & $.028^{*}$ \\
Market Feedback & .077 & .046 & .128 & 1.673 & .096 \\
\hline
\end{tabular}

Level of significance: $* 0.05 ; * * 0.01$

The results from the table show that $32.6 \%$ of the variation in business performance can be explained by market focus, market action, market planning, market coordination, and market feedback. The model was also significant at $1 \%$ level $(\mathrm{F}=14.203$, sig. $\mathrm{F}=0.000)$. Two of the predictor variables were found to have statistically significant association with business performance. The two variables were market focus $(\beta=0.281$, $\mathrm{p}=0.001)$ and market coordination $(\beta=0.180$, $\mathrm{p}=0.028$ ). Thus, the results supported $\mathrm{H} 1(\mathrm{~b})$ and H1(e). It can be concluded that market focus was the strongest contributing predictor that explains $28.1 \%$ of the variance in business performance, followed by market coordination.

\section{DISCUSSION AND CONCLUSION}

The mixed results between the individual dimensions of market orientation and business performance of this study suggested that the overall hypothesis of the study was partially supported. The significant results on the impact 
of market orientation dimensions on business performance in the Malaysian manufacturing industry sample is consistent with some studies, which includes Jaworski and Kohli (1993), Kara, Spillan, and DeShields (2005), Loubser (2000), Narver and Slater (1990), and Pulendran et al. (2000). On the other hand, the non-significant results on the relationship between market orientation dimensions and business performance in the Malaysian manufacturing industry sample is in-line with some studies, which includes Appiah-Adu (1998), Bhuian (1997), Caruana et al. (1999), Greenley (1995), and Langerak et al. (2004). Studies such as Appiah-Adu (1998), Bhuian (1997), Dawes (2000), and Greenley (1995) reported a non-significant relationship between market orientation and financial performance. Other studies such as Langerak et al. (2004) revealed that market orientation was not significantly related to new product performance and overall organisational performance.

Although the result of the present study show mixed results the, overall model suggested that market orientation dimensions were significant in jointly explaining the variance of business performance. The evidence from this study suggested that high levels of market orientation practices are related to high levels of business performance. However, individual dimensions of market orientation that contributes strongly to the specific performance variables need to be taken into consideration by organisations that wish to implement market orientation practices. Specifically, organisations need to give attention to market focus practices as the results showed that market focus had a positive relationship and the greatest impact on business performance. Market focus has been identified as one of the basic elements and fundamentals of market orientation (Felton, 1959; Kohli \& Jaworski, 1990; Narver \& Slater, 1990). Some of the market focus practices that organisations should consider include building strategy for competitive advantage based on understanding of customer needs, encouraging customer comments and complaints, always looking at ways to create customer value in products, and measuring customer satisfaction on a regular basis.

Another important element that organisations should take into consideration in its practices is market coordination. Market coordination is also an integral part of market orientation and the findings indicated that it is the second dimension after market focus that had significant impact on business performance. The main activity in market coordination is sharing of information between functions in the organisation. Since market focus involves collecting information on customer needs and satisfaction, sharing the information to other departments, especially the operations department, may enhance the quality of product produced.

The findings of this study contribute to the existing body of knowledge by providing empirical evidence on the relationship between market orientation and business performance in a developing country. Literature pointed out that there is limited research that had been conducted in developing countries. The literature also noted that the positive association between market orientation and performance does not necessarily hold true in developing countries (Appiah-Adu, 1998; Bhuian, 1997). There could be differences in terms of economic structure, regulation aspect, competitive environment, and the people elements, which is unique to a particular country. As specified by Yoon and Lee (2005), countryspecific factors may affect the market-oriented practices. This is especially relevant in developing countries where the business environment and other unique factors in one particular country are taken into account. Therefore, more studies need to be undertaken in developing nations and other countries besides the western culture in which business environment differs. This will ensure that market orientation is not a concept unique to western companies (Appiah-Adu, 1998; Ellis, 2005; Kuada \& Buatsi, 2005; Sin et al., 2004). Managers may also consider the result of the study by practising market orientation in their efforts to strive for achieving better organisational performance. 


\section{REFERENCES}

Agus, A. (2004). TQM as a focus for improving overall service performance and customer satisfaction: An empirical study on a public service sector in Malaysia. Total Quality Management, 15(5/6), 615-628.

Appiah-Adu, K. (1998). Market orientation and performance: Empirical tests in a transition economy. Journal of Strategic Marketing, 6(1), 25-45.

Appiah-Adu, K., \& Ranchhod, A. (1998). Market orientation and performance in the biotechnology. Technology Analysis \& Strategic Management, 10(2), 197.

Baker, W. E., \& Sinkula, J. M. (1999). The synergistic effect of market orientation and learning orientation on organisational performance. Journal of the Academy of Marketing Science, 27(4), 411.

Barksdale, H. C., \& Darden, B. (1971). Marketers“ attitudes toward the marketing concept. Journal of Marketing, 35(4).

Bhuian, S. N. (1997). Exploring market orientation in banks: An empirical examination in Saudi Arabia. Journal of Services Marketing, 11(4/5), 317.

Cadogan, J. W., Diamantopoulos, A., \& Siguaw, J. A. (2002). Export marketoriented activities: Their antecedents and performance consequences. Journal of International Business Studies, 33(3), 615.

Caruana, A., Pitt, L., \& Berthon, P. (1999). Excellence-market orientation link: Some consequences for service firms. Journal of Business Research, 44(1), 5-15.

Chakravarthy, B. S. (1986). Measuring strategic performance. Strategic Management Journal, 7(Sep/Oct), 437-458.
Chong, P. K. (2007, March 20). Show us how good you are. New Straits Times, p. 2.

Dawes, J. (2000). Market orientation and company profitability: Further evidence incorporating longitudinal data. Australian Journal of Management, 25(2), 173.

Day, G. S. (1994). The capabilities of marketdriven organisations. Journal of Marketing, 58(4), 37.

Deshpande, R., Farley, J. U., \& Webster, F. E., Jr. (1993). Corporate culture, customer orientation, and innovativeness in Japanese firms: A quadrad analysis. Journal of Marketing, 57(January), 23-27.

Diamantopoulos, A., \& Hart, S. (1993). Linking market orientation and company performance: Preliminary evidence on Kohli and Jaworski's framework . Journal of Strategic Marketing, 1(2), 93.

Economic Planning Unit. (2005). Mid-term review of the eighth Malaysia plan. Retrieved January 23, 2006, from www.epu.jpm. my/

Ellis, P.D. (2005). Market orientation and marketing practice in a developing economy. European Journal of Marketing, 39(5/6), 629-645.

Farrell, M.A. (2000). Developing a marketoriented learning organisation. Australian Journal of Management, 25(2), 201.

Felton, A.P. (1959). Making the marketing concept work. Harvard Business Review, 37(4), 55.

Gomes, C.F., Yasin, M.M., \& Lisboa, J.V. (2004). A literature review of manufacturing performance measures and measurement in an organisational context: A framework and direction for future research. Journal of Manufacturing Technology Management, 15(6), 511-530. 
Gray, B., Matear, S., Boshoff, C., \& Matheson, P. (1998). Developing a better measure of market orientation. European Journal of Marketing, 32(9/10), 884-903.

Greenley, G. E. (1995). Market orientation and company performance: Empirical evidence from UK companies. British Journal of Management, 6(1), 1.

Hooley, G.J., Lynch, J.E., \& Shepherd, J. (1990). The marketing concept: Putting the theory into practice. European Journal of Marketing, 24(9), 7-24.

Horng, S.C., \& Cheng-Hsui Chen, A. (1998). Market orientation of small and mediumsized firms in Taiwan. Journal of Small Business Management, 36(3), 79-85.

Jaworski, B.J., \& Kohli, A.K. (1993). Market orientation: Antecedents and consequences. Journal of Marketing, 57(3), 53.

Kaplan, R.S. (1983). Measuring manufacturing performance: A new challenge for managerial accounting research. Accounting Review, 58(4), 686-703.

Kaplan, R.S., \& Norton, D.P. (1992). The balanced scorecard- measures that drive performance. Harvard Business Review, January-February, 71-79.

Kaplan, R. S., \& Norton, D.P. (1993). Putting the balanced scorecard to work. Harvard Business Review, September-October, 134-142.

Kaplan, R. S., \& Norton, D.P. (1996a). Translating strategy into action: The balanced scorecard. Boston: Harvard Business School Press.

Kaplan, R. S., \& Norton, D.P. (1996b). Using the balanced scorecard as a strategic management system. Harvard Business Review, 74(1), 13-30.
Kaplan, R. S., \& Norton, D. P. (2001). The strategy focused organisation: How balanced scorecard companies thrive in the new business environment. Boston: Harvard Business School Press.

Kara, A., Spillan, J. E., \& DeShields O. W., Jr (2005). The effect of a market orientation on business performance: A study of smallsized service retailers using MARKOR scale. Journal of Small Business Management, 43(2), 105-118.

Kohli, A. K., \& Jaworski, B. J. (1990). Market orientation: The construct, research propositions, and managerial implications. Journal of Marketing, 54(2), 1-18.

Kohli, A. K. \& Jaworski, B.J. (1993). MARKOR: A measure of market orientation. Journal of Marketing Research (JMR), 30(4), 467.

Kotler. (2003). Marketing management $\left(11^{\text {th }}\right.$ ed.). New Jersey: Prentice Hall.

Kotler, P. (1972). Marketing management: Analysis, planning and control, 2. New Jersey: Prentice-Hall.

Kotler, P., \& Levy, S. J. (1969). Broadening the concept of marketing. Journal of Marketing, 33(1)

Krejcie, R. V., \& Morgan, D. W. (1970). Determining sample size for research activities. Educational and psychological measurement, 30, 607-610.

Kuada, J., \& Buatsi, S. N. (2005). Market orientation and management practices in ghanaian firms: Revisiting the Jaworski and Kohli Framework. Journal of International Marketing, 13(1), 58-88.

Kumar, N., Stern, L. W., \& Anderson, J. C. (1993). Conducting inter-organisational research using key informants. Academy of Management Journal, 36(6), 1633-1651. 
Langerak, F., Hultink, E. J., \& Robben, H. S. J. (2004). The role of predevelopment activities in the relationship between market orientation and performance. $R \&$ D Management, 34(3), 295-309.

Lee, T.S., \& Tsai, H.J. (2005). The effects of business operation mode on market orientation, learning orientation and innovativeness. Industrial Management and Data Systems, 105(3), 325-348.

Loubser, S. S. (2000). The relationship between a market orientation and financial performance in South African organisations. South African Journal of Business Management, 31(2), 84.

McCarthy, E. J., \& Perreault Jr., W. D. (1993). Basic Marketing $\left(11^{\text {th }}\right.$ ed.). Boston: Irwin.

McNamara, C. P. (1972). The present status of the marketing concept. Journal of Marketing, $36(1)$.

MoF. (2006). Economic performance and prospects. Retrieved April 16, 2006, from www.treasury.gov.my/index.php

Munsinger, G. M. (1964). Total marketing: The role of the marketing concept in 112 leading industrial organisations. Unpublished $\mathrm{PhD}$, University of Arkansas, USA.

Narver, J. C., \& Slater, S. F. (1990). The effect of a market orientation on business profitability. Journal of Marketing, 54(4), 20.

Parasuraman, A. (1981). Hang on to the marketing concept. Business Horizons(December), 38-40.

Pelham, A. M. (1997). Mediating influences on the relationship between market orientation and profitability in small... Journal of Marketing Theory and Practice, 5(3), 55.

Pelham, A.M., \& Wilson, D.T. (1996). A longitudinal study of the impact of market structure, firm structure, strategy, and market orientation culture on dimensions of small-firm performance. Journal of the Academy of Marketing Science, 24(1), 27.

Pitt, L., Caruana,A., \& Berthon, P.R. (1996). Market orientation and business performance: Some European evidence. International Marketing Review, 13(1), 5.

Pulendran, S., Speed, R., \& Widing, R. E., II (2000). The antecedents and consequences of market orientation in Australia. Australian Journal of Management, 25(2), 119.

Ruekert, R.W. (1992). Developing a market orientation: An organisational strategy perspective. International Journal of Research in Marketing, 9(3), 225-245.

Shoham, A., \& Rose, G.M. (2001). Market orientation: A replication, cross-National comparison, and extension. Journal of Global Marketing, 14(4), 5.

Sin, L.Y.M., \& Tse, A. C. B. (2000). Market orientation and business performance: An empirical study in Mainland China. Journal of Global Marketing, 14(3), 5.

Sin, L.Y.M., Tse, A.C.B., Yau, O.H.M., Lee, J.S.Y., \& Chow, R.P.M. (2004). Market orientation and business performance in the PRC: A regional comparison. Journal of Global Marketing, 17(2/3), 55-89.

Sinclair, D., \& Zairi, M. (1995). Effective process management through performance measurement: Part 1- applications of total quality-based performance measurement. Business Process Re-engineering, 1(1), 75-88.

Singh, S. (2004). Market orientation, corporate culture and business performance. Hants: Ashgate.

Slater, S.F., \& Narver, J. C. (1994). Does competitive environment moderate the market orientation-performance relationship? Journal of Marketing, 58(1), 46. 
Soehadi, A.W., Hart, S., \& Tagg, S. (2001). Measuring market orientation in the Indonesian retail context. Journal of Strategic Marketing, 9(4), 285-299.

Trustrum, L.B. (1989). Marketing: Concept and function. European Journal of Marketing, 23(3), 48-56.

Venkatraman, N., \& Ramanujam, V. (1986). Measurement of business performance in strategy research: A comparison of approaches. Academy of Management Review, 11(4), 801.
Vorhies, D.W., \& Harker, M. (2000). The capabilities and performance advantages of market-driven firms: An empirical investigation. Australian Journal of Management, 25(2), 145-172.

Webster, F.E., Jr. (1988). The rediscovery of the marketing concept. Business Horizons, 31(3), 29.

Yoon, S.-J., \& Lee, S.H. (2005). Market-oriented culture and strategy: Are they synergistic? Marketing Bulletin, 16, 1-20. 